Paper presented at the 6th Toplcal Meeting on the Technology of Fusion Energy, San Francisco, CA, March 3-7, 1985; also for publication in Fusion Technology.

\title{
A SYSTEMATIC METHODOLOGY FOR ESTIMATING DIRECT CAPITAL COSTS FOR BLANKET TRITIUM PROCESSING SYSTEMS*
}

\author{
P. A. Finn \\ Fuston Power Program \\ Argonne National Laboratory \\ Argonne, IL 60439
The submitted manustript has been authored bra contractor of the U.S. Gouernment by a coctor Accordingly, the $U$ s. Government retains Accordinglv. the U. S. Government retains a nonexclusive, royalty-free Nicense to publish or reproduce the published form of this contribution, or allow others to do so. for U. S. Government purposes.

\begin{abstract}
DISCLAIMER
This report was prepared as an account of work sponsored by an agency of the United States Government. Neither the United States Government nor any agency thereof, nor any of their employees, makes any warranty, express or implied, or assumes any legal liability or responsibility for the accuracy, completeness, or usefulness of any information, apparatus, product, or process disclosed, or represents that its use would not infringe privately owned rights. Reference herein to any specific commercial product, process, or service by trade name, trademark, manufacturer, or otherwise does not necessarily constitute or imply its endorsement, recommendation, or favoring by the United States Government or any agency thereof. The views and npinions of authors expressed herein do not necessarily state or reflect those of the United States Government or any agency therenf.
\end{abstract}

Work supported by the U.S. Department. of Energy. 


\author{
P. A. Finn \\ Chemical Technology $\downarrow$. Ion, Argonne Nat Ional Laboratory \\ 9700 Sowth Cage Avenue \\ Argonne, IL 60439 \\ (312) 972-4511
}

\section{ABSTRACT}

This paper describes the ethodology developed for estinating the relative capital costs of blanket processing systens. The capital casts of the nine blanket concepts selected in the Blanket Comparison and Selection Study are presented and compared.

\section{INTRODUCTLON}

The primary goal of the Blanket ComparIson and Selection study was to evaluate different fualon blanket concepts in order to select those which had the cost favorable characteristics for a conaercial fusion reactor. Detalled selection criterla were generated in four areas: engineering feasibility, econowics, safety and RdD requirements.

An area in which ajor capical costa are Incurted is the blanket procesalng syeter. Because this aysten is an luportant part of each of the nine blanket concepts conaldered, it was necessary to develop self-consistent methodology whlch could be used to eatinete the reletive copital costo of each blanket procesaing aystew. Since there was vinial detalled inforastion for any of the blanket concepte, a relative costing basts was developed. Th1s paper deacribes the nethodology for costing a blanket processing systea and compares the results for the nine concepts selected in the Blanket Coaparioon and Select lon Study (BCSS).

\section{BASIC ASSUMPTIONS}

The t-anket oyoten Includes not only the blanket 1 taelf but also $a 11$ the necesesry aystems needed for its operation. This includes the safety syateas in the plont for control of trillue release. Because consistency was needed in the osalysis of the nine blanket recovery systems it wa conaldered adventageouv to arsume that each blanket recovery bysten could be separated Into cooponent aubsystens which could be Individually conted. The totel coet for a given blenket concept wes the total of all component gubsytems. Sybtems common to each of the blanket concepta would thus be based on a coman relative basis. The Individual ccaponents were these: 1) blanket tritiun recovery and sosociated tritiun purification syster; 2) processing eysteas for the blanker coolant to control tritlue dgration into the reactor hall and/or the heat exchanger syoteas; 3) coolant purification sycteas; 4) coolant duep tanks; and 5) triflu extraction eystems for tritiun recovery fros blanket adules rewoved fron the reactor. The cost of tritiun control in linter/firat wall or halo scraper/direct convertor systen were also Included ince for some blanket concepts. - comon tritiun recovery syoten could be used shich would reduce coste. The sumation or each of these coste is the total capital cost of the blanket processing syste. To provide a total capital cost of the processing agsten needed for a fusion reactor, fuel processing coste and the eteoepheric rritiun tecovery coste vere added to the blanket processing costa. The capital cost of water purification systens we assumed to be included in the balance of plant cost.

Information on each of the nine blenket concepte was provided by the responsible deaign tean In the alanket comparison and Seiection study. This date is sumarized In Table 1 for tre cokaask designe and in Table 2 for the randen airror designs. The inforention in these tablea is the date uaed for costing the blanket procesaing sjoter needed for each blanket concept.

\section{METHODOLOGY}

The nine blanket concepte are asauned to be apezated in elther a tokanak (STARFIRE reference) ${ }^{2}$ or arror (AMrs reference) ${ }^{3}$ reactor. The fusion poure produced by thes: reactors to 4000 mil and 3200 mis respectively, The capical cost of a fuel proceselns syaten for reactors of this ofre inciudes both fixed cost portion ( $\$ 20$ X) and verieble cost $(\$ 10-20 \mathrm{~K})$ dependent on the chrourhput of the resctor. Since this veriable cost is dir- 


\section{REPRODIICED FROM \\ BEST AVAILABLE COPY}

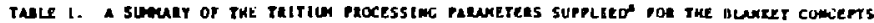

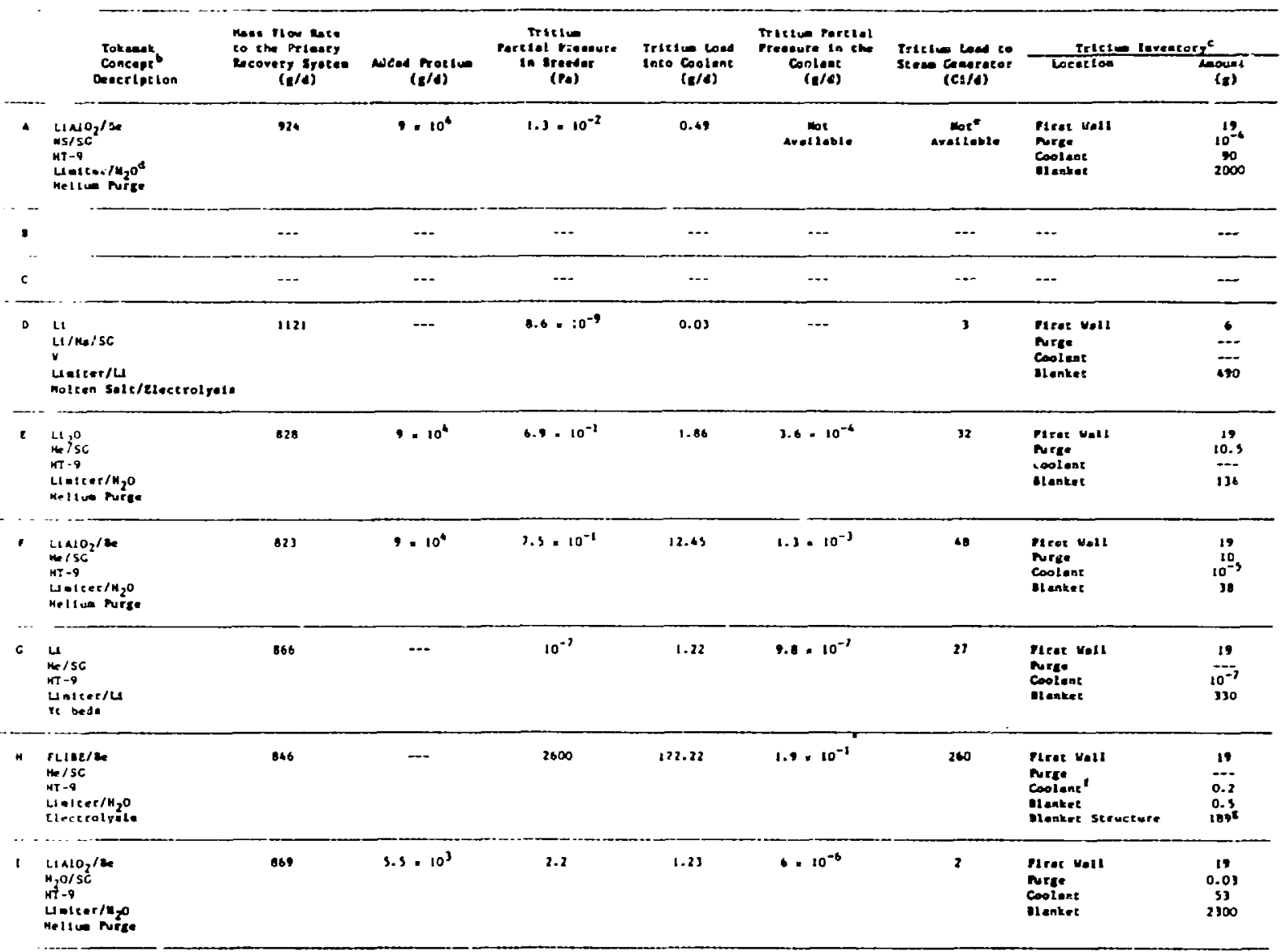

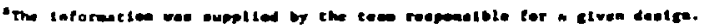

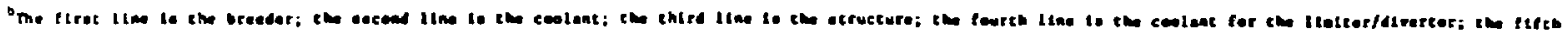

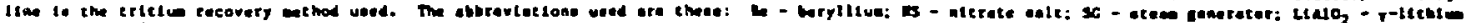

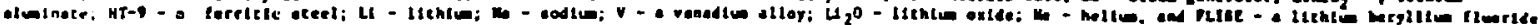
ale.

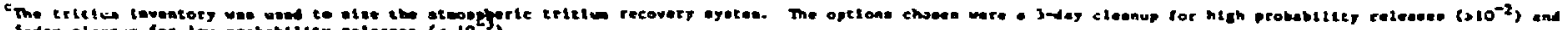

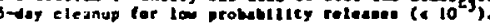

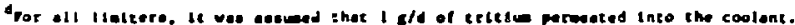

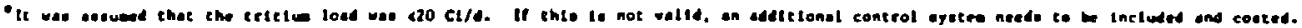

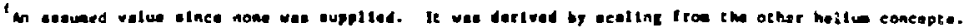

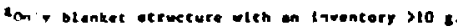




\section{REPPODUCED FROM \\ BEST AVALAABLE COPY}

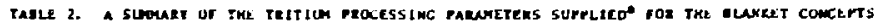

\begin{tabular}{|c|c|c|c|c|c|c|c|c|c|}
\hline & $\begin{array}{l}\text { Mtriog } \\
\text { Concepsb } \\
\text { Decertption }\end{array}$ & 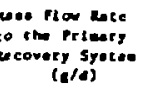 & $\underset{(a / d)}{\text { Mdeed Fot }}$ & $\begin{array}{l}\text { Trictes } \\
\text { Porchet Preanure } \\
\text { in Orewder } \\
\text { (Pa) }\end{array}$ & $\begin{array}{c}\text { Trtel = lood } \\
\text { Into cootent } \\
(a / d)\end{array}$ & 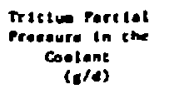 & $\begin{array}{l}\text { Tritlus lond to } \\
\text { stoed Centrentor } \\
\text { (Cild) }\end{array}$ & Tocetton & $\frac{\cos }{\cos (1)}$ \\
\hline A & 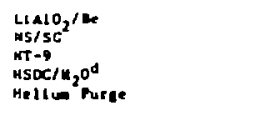 & 019 & 1. $10^{4}$ & $1.3 \cdot 10^{-2}$ & 0.43 & $\underset{\text { notlesile }}{\text { not }}$ & $\underset{\text { aveltable }}{\operatorname{mot}}$ & 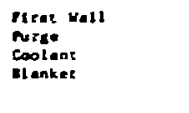 & $\begin{array}{c}3.1 \\
10^{-4} \\
50 \\
150\end{array}$ \\
\hline - & 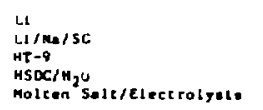 & 386 & -- & $8.6=10^{-9}$ & 0.02 & $\ldots$ & 2 & $\begin{array}{l}\text { Firat vall } \\
\text { nurge } \\
\text { Coolent } \\
\text { elanket }\end{array}$ & 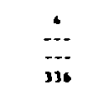 \\
\hline c & $\begin{array}{l}\text { WPo } \\
\text { WPW/SC } \\
\text { v } \\
\text { HSOC/E, } \\
\text { Councer }\end{array}$ & 13: & $4.2 \cdot 10^{6}$ & $1.3 \cdot 10^{-4}$ & ... & - & 10 & $\begin{array}{l}\text { Tizet vall } \\
\text { Murge } \\
\text { Coolant } \\
\text { slanket }\end{array}$ & $\frac{1}{<1}$ \\
\hline 0 & 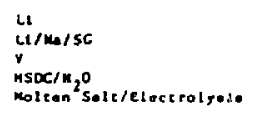 & Iss & $\ldots$ & $0.6 \cdot 10^{-9}$ & 0.02 & $\ldots$ & 2 & 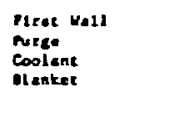 & $\frac{1}{-136}$ \\
\hline e & 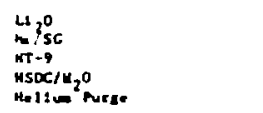 & 580 & $3.6 \cdot 10^{4}$ & $7.8=10^{-1}$ & 0.es & $6.4=10^{-4}$ & 20 & $\begin{array}{l}\text { Plrat Hall } \\
\text { purge } \\
\text { Coliant } \\
\text { otentet }\end{array}$ & $\frac{1}{10^{-3}}$ \\
\hline , & 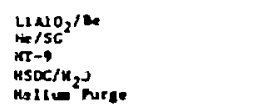 & ss & $9.7 \cdot 10^{4}$ & B.t $\cdot 10^{-1}$ & 0.31 & $\begin{array}{c}1.9 \cdot 10^{-3} \\
.\end{array}$ & 43 & $\begin{array}{l}\text { Pirae vall } \\
\text { Arce } \\
\text { Coolent } \\
\text { viankes }\end{array}$ & $10^{4}$ \\
\hline$c$ & 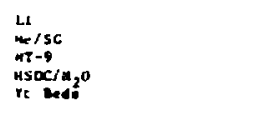 & 358 & $\cdots$ & $1.1 \cdot 10^{-1}$ & 0.2 & $1.8=10^{-7}$ & 17 & 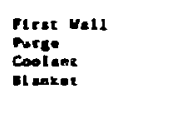 & $\frac{6}{10^{-7}}$ \\
\hline$\star$ & 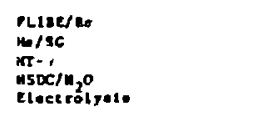 & $\$ 12$ & -- & 2000 & 63.2 & $1.0 \cdot 10^{-1}$ & (9) & 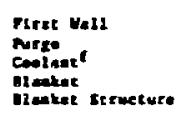 & $\frac{1}{0.16}$ \\
\hline 1 & 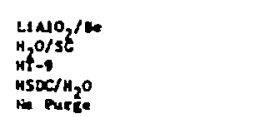 & 386 & $3.7=10^{3}$ & 1.2 & 0.21 & $6.10^{-6}$ & 2 & 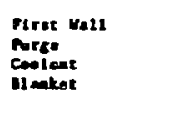 & $\begin{array}{c}0.03 \\
53 \\
1500\end{array}$ \\
\hline
\end{tabular}

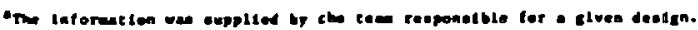

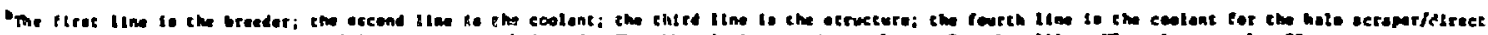

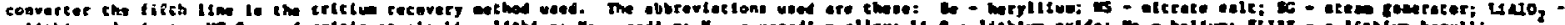

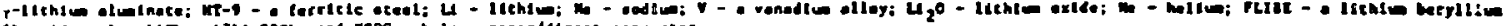

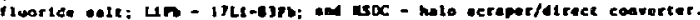

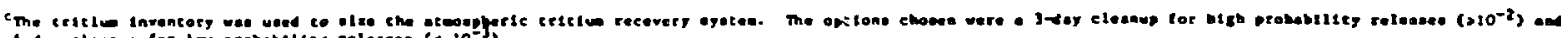

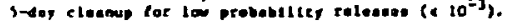

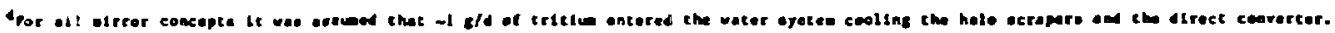

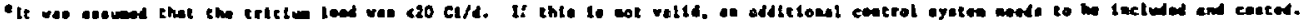

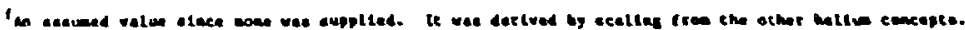

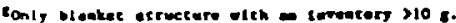


ectly proportional to the fusion power and inversely proportional to the fractional burn, the capital cost of the fuel processing syster of the wirror reactor which has a fusion power -80 \% of the tokamak's and f fractionsl burn $-140 \pi$ of the tokamak's 1 s $\$ 31$ at1lion and the tokamak's is $\$ 40$ million.

\section{A. Atmospheric Tritlum Recovery}

An atmospheric tritlum recovery system (ATR) processes the atmosphere to reduce the tritium concentration Bfer a tritium releage to levels $<50 \mu \mathrm{MC} / \mathrm{m}^{3}$. Releases are assumed to occur dūring mantenance or under accident conditions. The captal cost of the system needed for a given reactor hall is a function of the hall's size, 1.e. volume, and also of the processing rate. Por BCSS, the baseline voluwe for voth the tokamak and the mirror deslgns was $2 \times 10^{5} \mathrm{~m}^{3}$. The processing rate considered adequate for a comerclal power plant 18 one which can process releases with a high probability of occurrence $\left(p>10^{-2}\right)$ in three days and those with a lower probability of occurrence $\left(p \leq 10^{-3}\right)$ in five dayg. The tradeoff between the size of a release and the capital cost of the ATR needed $1 \mathrm{~s}$ shown in Table 3. It is assumed that in a commercial power plant, the most likely accionent $t_{8}$ breakage of "pipe containing gaseous tritiura. Amounts released would be of the order of $10 \mathrm{~g}$. This also 18 the amount of tritlum in the first wall of all seven tokamak blanket concepts (Table 1). Accldents wh lower probabilicy would include release of all tritLum in the blankets of Concepts B, G, or D ( 1 $\mathrm{kg}$ ) or Concepte $A$ or I $(\leq 2.3 \mathrm{~kg}$ ) (Tables 1 and 2). A gystem with a capital cost of $\sim \$ 36$ mil. lton provides cleanup of events with high probability in $\sim 3$ days and events with low probability in $\sim 5$ days. Since the ATR in the reactor hall handles releases from systems other chan the blanket, this 18 probably the optimur system that can be specifled with the ligited Inforwation avallable.

\section{B. Iaplantacion Triciur Concrol}

The size of che tritiun control system for the Ilalter/divertor or the halo scraper/ direct convertor depends on the rate of tritlum Implantation and algration. It la assumed for this study that this is equivalent to 1 g/d for all designs. The liater coolant is efther lithium or vacer. It 18 assumed that for dithiun coolant, the cost of removing the tritius is swall increwent to the blenket crictur removal syatew. For water the gereral equation for the caplcal cost, $c$, of removing tritsur frod water coolant using CECE (combined electrolysia and chenical exchange) 1a:

$C(S M)=15\left[\frac{(C 1 / d)}{(C 1 / L)(1000)(L / d)}\right]^{0.55}$.

If teitlum levels of $\mathrm{I} \mathrm{Cl} / \mathrm{L}$ are mintalned in the wate: coolant, and water is processed at
TABLE 3. CAPITAL COST OF ATR SYSTEM AS FUNCIION OF PROCESSING RATE ${ }^{a}$

$\begin{array}{ccc}\text { Release } & \text { Cost }(72 \mathrm{~h}) & \operatorname{Cost}(120 \mathrm{~h}) \\ (\mathrm{g}) & (\mathrm{SH}) & (\mathrm{SM})\end{array}$

\begin{tabular}{rll}
\hline 10 & $36^{\mathrm{b}}$ & 25 \\
50 & 40 & 28 \\
100 & 42 & 29 \\
500 & 46 & 32 \\
1000 & 48 & 33 \\
2300 & 50 & $35^{\mathrm{b}}$ \\
\hline
\end{tabular}

- Cleanup to $50 \mu \mathrm{Cl} / \mathrm{m}^{3}$ for a volume $2 \times 10^{5}$ $\mathbf{m}^{3}$. (Ref. 5).

b The same system cleans up a $10 \mathrm{~g}$ release in $72 \mathrm{~h}$ or a $2.3 \mathrm{~kg}$ release in $120 \mathrm{~h}$.

the rate of $10^{2}, 10^{3}, 10^{4}$ or $10^{5} \mathrm{~L} / \mathrm{D}$, then the capital cost 186,15 , 50 or 100 atilion dollars, respect 1 vely.

\section{Blanket-Trit Ium Recovery and Purification}

There are rwo types of tritlum recovery and purffication systems considered: the f1rst 18 that associated wth solld breeders $\left(\mathrm{LI}_{2} \mathrm{O}, \mathrm{LIAlO}_{2}\right)$; the second to that assoctaced with ilquid breeders (L1, LiPb, Flibe).

For the solid breeder, an In-situ tritiur recovery system consists of a hellum purge streas with associated pumps, and a system for removing tritium from the purge stresw. In addition, there is a tritiun purification systen, aystem for handing protlum for tritiua control, and a system for removing tritlum from discarded solid braeder modules.

For the liquid breeder, there is a basic trictum recovery aystem consisting of sets of cycled yttriua getters, a multen salt/electrolysis unft, counter-current helium flow ayscen, or an electrolysis unit. In addicion, there is tritiue purification systen and a system for processing protiun if this is necessary for control of tritlum in the heat exchanger.

The capital cost associlaced wh the tritlum recovery system for both liquid and solld breeders was determined as follows. A base design which could process $600-800 \mathrm{~g} / \mathrm{d}$ was assumed for boch cokasak and mitror wachlnes. Higher processing races $>800 \mathrm{~g} / \mathrm{d}$ yould be handled by a larger systen whose capital cost yould be an increaent of the base cost. To a first epproxigation, it was asaused that each blanket tritlum recovery eystea would be of conparable cost. Since there are not pilot plant versions of these syoteas it us asaused that the capital cost 
would be approximated by costing olmilat equipment in other industries. This cost could be increased by an appropriate factor to account for the tritiun requirement - l.e., all Detal systems, peraeation barriers, etc. The unit which served as a baseline for derivIng capital costs was a centrifugal contactor. These units are used in the chemical Industry and one has been designed for use in fission fuel reprocessing. The cost of this unlt was scaled to derive the cost of one needed to process liquid metals. The volume of materlal in the liquid metal designs was $-10^{6} \mathrm{~L}$. If ch1s volume $1 \mathrm{a}$ processed 100 times a day the processing rate le $4 \times 10^{5} \mathrm{~L} / \mathrm{mln}$. The capital cost of an unheated one-state contactor not designed for use with tritlum is $\$ 2.5 \mathrm{M}$; for a four-state contactor, the cost is $\$ 4.4 \mathrm{M}$. The estruated capital cost of a four stage unit which could be used at high cemperature and with tritium is estimated at $\$ 10 \mathrm{M}$. The cost of each trittum recovery unit is thus assumed to be $\sim \$ 10 \mathrm{M}$. For processes like rolten salt extraction where two different procesing units are needed, a centrifugal conlactor and an electrolysis unit, the capital cost of the base ayster 18 assumed to be the cost of two base undts, 1.e. $\$ 20 \mathrm{M}$. For tokanak Concept D, $1100 \mathrm{~g} / \mathrm{d} 1 \mathrm{~s}$ processed; cherefore an incremental cost of $\$ 11$ is incurred for the tritiun recovery system.

The tritium purification systed rewoves both gamma and other impurities from the recovered tritium. The estimated cost of this unft 18 \$ $10 \mathrm{~K}$ which includes not only the base units $(\sim 5 \mathrm{M})$ but also the support systems needed since these units will be located efther in a hot cell area or in heat exchanger buliding. The tritius purlfication systed for $17 \mathrm{~L} 1-83 \mathrm{~Pb}$ is expected to cost $\sim \$ 15$ $M$ because large amounts of gaseous activated impurity 13 expected.

The addition of protfiun ( 5 to $90 \mathrm{~kg} / \mathrm{d}$ ) to the heat exchanger syster to reduce tritiun permeation in the heat exchanger requires. processing unit. This unit resoves tritium from the protium as well as other impuritles. To provide perspective, the fuel processing oystem is expected to handle $<10 \mathrm{~kg} / \mathrm{d}$ of deuterium and tritiun. The capital cost Incurted for adding a protiuw unit is deterwined from the following equation:

$$
\left.C(\$ H)=3 \times 10^{6} \text { (throughput }(g) / 1160\right)^{0.4}
$$

For 5, 50 and $90 \mathrm{~kg} / \mathrm{d}$, the capital cost ia $\$ 5$ $M, \$ 14 M$ and $\$ 17 M$, respect: ively.

The capital cost for the subayatem blanket-tritium recovery and purification for Tokamak Concept D 1a $\$ 41 \mathrm{H}, 1 . \mathrm{1}$. $(\$ 10+\$ 10+$ $\$ 11+\$ 10)$. This includes i) the cost of 2 base processing units pluis the increwent for the larget unit, and 2) the tritiun purifica- tion systed. For Mirror Concept $C$, the capital cost for the Eubsystem blanket tritium recovery and purificalion 16 \$51 $M, 1 . e$ ( $\{10$ $+13)+15+13)$. Thls includes the cost of 1) a base processing unte plus the incresent for a larger unte, 2) a tritiue purification system, and 3) a protlum cleanup system. See Table 4 for a sumary of these costs for all blanket concepts.

\section{Tritlum Extraction}

An extraction system will be needed to remove tritlum from diacarded solid breeder codules. The capital cost of a unit to be this, including all secondary systecs, Is estimated at $\sim \$ 10 \mathrm{M}$.

\section{E. Coolant - Tritium Recovery and} Purification

The tritlum load into the blanket coolant is the sum of the contributions from the first wall $(\leq 0.2 \mathrm{~g} / \mathrm{d})$, frow the 11 alte:/divertor system $(<1 \mathrm{~g} / d)$ from the hellum purge ( $\leq 0.02$ to $113 \mathrm{~g} 7 \mathrm{~d}$ ) and from the beryll1um mulitiplier ( $\leq 6$ to $9 \mathrm{~g} / \mathrm{d}$ ). The beryllium wultiplier contribution applies only to Concepts $F$ and $H$. In Concept $H$, the Flibe design, the tritium pecteating into the hellum coolant from the hellum purge otream is extremely large, 113 $\mathrm{g} / \mathrm{d}$ and $83 \mathrm{~g} / \mathrm{d}$ respectively for the tokamak and wirror degigns.

The cooliant tritius recovery systea conolsts of a ritiun resoval Bysten, tritiun purification system, special heat exchangers and piping, and a tritiun removal syoted for the steam generator. The latter is required If the tritlum input to the stean generator exceeds $20 \mathrm{Cl} / \mathrm{d}$. Its cost 1 o deternined fros Eq. (1).

The capital cost of the tritiua recovery systems for coolants other than water la assuned to be $\$ 10 \mathrm{M}$ for tritlum recovery and $\$ 10 M$ for tritfum purification. For pressurized hellun, the base tritiun recovery ayated 18 also assumed to cost $\$ 10 \mathrm{Mi}$ chis base system 18 assumed to remove $0.2 \mathrm{~g} / \mathrm{d}$. When large anounts of tritiun are renoved from helluw, the capltal cost increases. An estiwate of these costs are $\$ 4, \$ 14, \$ 40$, and $\$ 60$ If as the processing race Increases frow 1 to 10 to 80 to $120 \mathrm{~g} / \mathrm{d}$.

For Concept I, L $1 \mathrm{AlO}_{2}$ /water coolant, the major capital cost asocisted with coolant triciuw recovery is included in the cost fur triciua control in the 11 alter/divertor. The increantal capital cost of a larger ayotea wth additional capacity is $\$ 10 \mathrm{H}$. For Concept $C$, part of the capital cost ef coolanttritius renoyal is included in blanket-tritiun recovery since this io aelf-cooled eysten. The capital coste for apeciel heat exchanger: and piping and coolant crictur recovery needed becauce of the high trittur partial preseure 


\section{REPPODUCED FROM BEST AVAILAELE COPY}

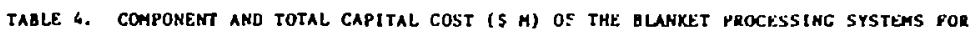
NINE DIFFERENT BLANKET CONCEPTS IN BOTH TOKAMAK AND MIRROR HEACTORS

\begin{tabular}{|c|c|c|c|c|c|c|c|c|c|c|c|c|c|c|c|c|}
\hline Process & $\wedge$ & D & $\mathbf{E}$ & $\begin{array}{l}\text { Tokanak } \\
\text { F }\end{array}$ & Cone & pte & 1 & $\wedge$ & $B$ & C & $\begin{array}{c}\text { Merror } \\
\text { D }\end{array}$ & $\begin{array}{l}\text { Concepte } \\
\text { E }\end{array}$ & $\mathbf{F}$ & c & и & 1 \\
\hline \multicolumn{17}{|l|}{ Blanket cubsysteas } \\
\hline $\begin{array}{l}\text { l.Inicer/Olvercor }\left(\mathrm{H}_{2} \mathrm{O}\right) \\
\text { or Halo Screper }\left(\mathrm{H}_{2} \mathrm{O}\right)\end{array}$ & so & --- & so & so & --- & so & so & 50 & so & su & 50 & so & 50 & so & so & so \\
\hline $\begin{array}{l}\text { Blanket-Trteliu Recov- } \\
\text { ery ding Purtllication }\end{array}$ & 40 & 41 & 37 & 3) & 32 & $2 t$ & 27 & 40 & 30 & 51 & 40 & 36 & 36 & 30 & 23 & 25 \\
\hline $\begin{array}{l}\text { Coolani-Triclue Recon- } \\
\text { ery and Purifleation }\end{array}$ & 20 & 20 & 28 & 44 & 28 & 90 & 10 & 20 & 20 & 20 & 20 & 24 & 36 & $\because$ & 70 & 10 \\
\hline $\begin{array}{l}\text { Coolane Purificacton } \\
\text { NS, He, Ma } \\
\text { LI, LIPo, FLIBE }\end{array}$ & $\begin{array}{r}10 \\
---\end{array}$ & $\begin{array}{l}10 \\
10\end{array}$ & 10 & 10 & $\begin{array}{l}10 \\
10\end{array}$ & $\begin{array}{l}10 \\
10\end{array}$ & --- & $\begin{array}{r}10 \\
---\end{array}$ & $\begin{array}{l}10 \\
10\end{array}$ & --- & $\begin{array}{l}10 \\
10\end{array}$ & 10 & 10 & $\begin{array}{l}10 \\
10\end{array}$ & $\begin{array}{l}10 \\
10\end{array}$ & --- \\
\hline $\begin{array}{l}\text { Coolant Dump Tanks } \\
\text { NS. W } \\
\text { Ll. LIPb, FLISE }\end{array}$ & $\begin{array}{r}5 \\
--\end{array}$ & $\begin{array}{l}5 \\
5\end{array}$ & $\ddot{--}$ & --- & s & --- & --- & 5 & 3 & -- & $\begin{array}{l}3 \\
5\end{array}$ & $=$ & $\cdots$ & --- & $--\bar{s}$ & $=-$ \\
\hline $\begin{array}{l}\text { Teletun Exeraction } \\
\text { (DIscarded Modules) }\end{array}$ & 10 & --- & 10 & 10 & $-\cdots$ & --- & 10 & 10 & $-\infty$ & $-\infty$ & -- & 10 & 10 & -- & $\ldots$ & 10 \\
\hline Blanket Processing & 135 & 91 & 135 & 151 & 85 & 186 & 97 & i3s & 230 & 146 & 140 & 128 & 140 & 229 & 168 & 95 \\
\hline Fuel processing & 40 & 40 & 40 & 40 & 40 & 40 & 10 & 31 & 31 & 31 & 31 & 31 & 31 & 31 & 31 & 31 \\
\hline$\Lambda T R^{a}$ & 36 & 36 & 36 & 36 & 36 & 36 & 36 & 36 & 36 & 36 & 36 & 36 & 36 & 36 & 36 & 36 \\
\hline TOTAL (Bene) & 211 & 167 & 211 & 227 & 161 & 262 & 173 & 202 & 197 & 213 & 207 & 195 & 207 & $19 \dot{~}$ & 235 & 162 \\
\hline
\end{tabular}

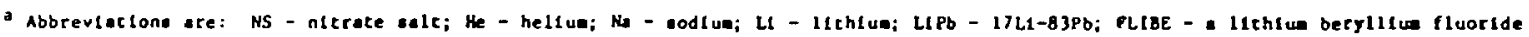
sali; ATR - atwospherle tritilue recovery.

$\left(10^{-4} \mathrm{~Pa}\right)$ in this syster is that shown in cooiant-tritium recovery - $\$ 20 \mathrm{M}$.

F. Coolant Purification

For each of the coolants, an Impurity removal system is necessary; the cost is est1mated at $\$ 10 \mathrm{M}$. For concepts with two coolants ( $B, D, G, H)$, the cost doubles because there are two impurity removal systems needed. Because the 17L1-83Pb system is regarded as highly corrosive, its impurity removal aystem is estimat ad at $\$ 20 \mathrm{M}$.

\section{G. Coolant Dump Tanks}

Dunp canks are provided for all coolant and/or liquid metal aystems. The estimated cost for the tank heating sytems and tritium control measures $1 \mathrm{~g} \sim \$ 5$ M for each dump tank required. Two concepts ( $B$ and $D$ ) require two dump tanks.

\section{DISCUSSION}

The total capital cost of the blanket processing system for each of the nine concepts is shown in Table 4. For a tokamak reactor, the capltal costs range frow $\$ 85 \mathrm{M}$ for Concept $G$ to $\$ 186$ H for Concept $H$, the Flibe design. The reason for Concept $\mathrm{H}^{\prime} \mathrm{G}$ high cost is the high tritiue partial pressure in the hellut coolant for flibe. The result 1s that addictonal tritium procesaing systems have to be added to control tritlum oigration throughout the fusion plant. The individual costs are: $\$ 21$ I $((20+1)+20)$ for blanketiritiun recovery and crielue pursficationi and \$90 M $((10+60)+10+10)$ for coolant- tritium recovery, tritium purification and tritlum control in the stean generators. The latter 18 required becanse of the $260 \mathrm{cI} / \mathrm{d}$ critlum influx (Table 1).

For a wrror reactor, the capital costs of the nine blanket processing systens range from $\$ 95 M$ for Concept I to $\$ 168$ H for Concept H. Concept H's capital costs are the highest for the reasons clted above. In the wirror designs, the relative capital costs of the concepta would change if the tritiun influx to the halo ocraper was assumed to be $0.1 \mathrm{~g} / \mathrm{d}$ rather than $1 \mathrm{~g} / \mathrm{d}$. The capital costs associated with implantation (halo screper) would be reduced by $\$ 35 \mathrm{~K}$ for 11 concept except $I$; for 1t, the reduction would only be $\$ 15 \mathrm{H}$ since a larger capacity aystem is needed to handle the blanket-tritlue recovery load. The ranking would be: A - \$100 M; B - \$95 M; C $\$ 111 \mathrm{M} ; \mathrm{D}-\$ 105 \mathrm{M} ; \mathrm{E}-\$ 93 \mathrm{~K} ; \mathrm{F}-\$ 105 \mathrm{M}$; G $\$ 94 \mathrm{M} ; \mathrm{H}-\$ 133 \mathrm{M}$; I - $\$ 80 \mathrm{M}$. The range is now from $\$ 80 M$ for Concept I to $\$ 13$ ? $M$ for Concept $H$. As can be seen, a change in one of the Input parawetera can easily charge a relative ranking of these concepts by blanket processing capltal cost. With $0.1 \mathrm{~g} / \mathrm{d}$ assuned as the tritium flux to the halo ecraper, the capital cost of all concepts except $H$ fit in the range $\$ 95 \pm 15 \mathrm{M}$. Concept $H$ is above thls range by $\sim \$ 25 \mathrm{M}$.

The final row in rable 4 la amary of all tritiun processing capital coste for the reactors eabodylng the nice blanket concepts considered. These costs range frov $\$ 261 \mathrm{M}$ to $\$ 252$ if conceft $h$ is included. If it 18 
excluded the range $1 \mathrm{~g}$ from $\$ 161 \mathrm{M}$ to $\$ 227 \mathrm{M}$.

v. RESULTS AND CONCLUSIONS

1) A methodology for determining the capital cost of the blanket processing systams for a fuston react or has been developed.

2) The methodology 18 based on the premise that the costs can be broken down into component parts and then sumed if Interfaces are Laken into account.

3) The methodology can be used to eatiogte the capltal costs of blanket concepts which are not highly detalled.

4) When several blanket proceasing systems are costed, the results Indicate which syoters have comparable costs and which systems have excessive capital costa.

5) The costs derived frow this methodology are a good estimate of the order of magnitude of the capital costs.

6) A detalled otudy of the total processing system for one blanket recovery system is needed to confirm the usefulness of this model.

\section{ACKNOWLEDGERENTS}

Th1s work wag supported by the U.S. Department of Energy, office of Fusion Energy.

REFERENCSS

1. D. L. SHETH, et al. "Blanket Comparfson and Selection Study Pinal Report,- ANL/PPP-841. Argonne National Laboratory (1984).

2. C. C. BAKER, et al., "STARPIRE - A Commerclal Tokamak Puolon Plant Study,Argonne National Laboratory Report, ANL/PPP80-1 (1980).

3. B. G. LOGAN, et al., "Mirror Advanced Reactor Study. Interlo Deslgn Repor,,Lawrence Livermore National Laboratory Report. UCRL-5333 (1983).

4. P. A. FINN, R. G. CLEMER, B. IISSRA, -Tritium Management Requirewents for $D-T$ Fusion Reactora,- (ETP, INTOR, PED), ANL-81-32 (1981).

5. M. A. ABDOU, et al., "FED-INTOR/TRIT/82-5, Chapter VIII - Trit1um and Blanket.

6. R. LEONARD, private comwunleation, Argonne Nat Ionel Laboratory. 